\title{
Advances in Low-Chilling Peach Breeding at Instituto Agronômico, São Paulo State, Brazil
}

\author{
W. Barbosa and \\ E.A. Chagas \\ Instituto Agronômico (IAC) \\ Campinas, São Paulo \\ Brazil
}

\author{
C.V. Pommer \\ Universidade Estadual do \\ Norte Fluminense (UENF) \\ Campos dos Goytacazes \\ Rio de Janeiro \\ Brazil
}

\author{
R. Pio \\ Universidade Estadual do \\ Oeste do Paraná \\ (UNIOESTE) \\ Paraná \\ Brazil
}

Keywords: Prunus persica, stone fruits, subtropical areas, cultivars, fruit quality

\begin{abstract}
Peach (Prunus persica L. Batsch), a typically temperate fruit tree, was introduced in Brazil through Portuguese colonization in the 1530s. Peach trees established at low latitude regions require climatic adaptation to subtropicaltemperate conditions of low-chilling. The first Brazilian peach breeding program was initiated by $O$. Rigitano in the late 1940s at the Instituto Agronômico (IAC). Research continued at IAC, aiming at full adaptation of selections to different climates of São Paulo State and other similar ecosystems. Pioneering peach crosses involved local and North American germplasm material of medium chilling requirement. Various low-chill and productive cultivars with high quality fruits were released. In the last decades, the best IAC cultivars $\left(F_{1}\right.$ and $F_{2}$ hybrids) were intercrossed with peach and nectarine selections from the University of Florida. Fifty eight cultivars were released for areas with 0-200 chilling hours (below $7.2^{\circ} \mathrm{C}$ ). The main fruit traits are: epidermis - green ('Talismã', 'Nectar', 'Cristal'), yellow ('Canário'), pink ('Jóia-1 and 2'), red ('Centenário'); flesh - yellow ('Petisco-2', 'Dourado-1'), white ('Natal', 'Delicioso Precoce', 'Jóia-4'); texture - firm, nonmelting ('Aurora-1'), soft ('Tutu', 'Catita', 'Jóia-3'); stone - cling ('Colibri', 'Brasão'), free ('Dourado-2', 'Jóia-5'); flavor - sweet ('Supermel', 'Ouromel-2'), sweet-acid ('Petisco', 'Arlequim'), canning ('Régis', 'Biuti'); maturation - early ('Tropical-1 and 2'), medium ('Aurora-2', 'Doçura-2'), late ('Bolão', 'Momo'); extra-large size ('Douradão'), and others, as shape - globose, oblong, round, with or without tip; pubescence - high, medium, low; dual purpose (fresh-canning). About $46 \%$ of 58 cultivars has yellow flesh, $54 \%$ white flesh, $47 \%$ rose and red skin, $53 \%$ green and yellow skin, $65 \%$ are freestone and $35 \%$ clingstone, being $10 \%$ canning. IAC peach harvest occurs from August to February, about 80-180 days after full bloom. These cultivars, and other genotypes with better pomological characteristics, have been widely accepted by fruit growers and consumers, due to the adequate evolution of peach cultivation in subtropical areas.
\end{abstract}

\section{INTRODUCTION}

Peach has been cultivated during centuries in the Orient, Europe and Americas at high latitudes (30 and $50^{\circ}$, North and South), with 500 to 2,000 hours accumulation of temperatures below $7.2^{\circ} \mathrm{C}$. Typically from a temperate climate, peach tree introduced at low latitude $\left(22^{\circ} \mathrm{S} \pm 2^{\circ}\right)$ requires climatic adaptation to subtropical conditions of low chilling (Barbosa et al., 2000).

In Brazil, the first peach breeding program aiming adaptation of cultivars to different habitats was developed by Instituto Agronômico (IAC), beginning at the end of the 1940's (Barbosa et al., 1990d).

As a result, cultivars such as 'Tutu' and other old varieties from the 1960's and 1970's had small fruit, green skin and were late ripening ones. From 1950 to 1990, many cultivars were released in São Paulo, Brazil (Instituto Agronômico, 1980; Rigitano and Ojima, 1971, 1986, 1988). Taking advantage of better pomological characteristics from one side and adequate evolution of peach orchard management on the other side, these 
cultivars have been widely accepted by fruit growers in areas with 50-100 hours of chilling or less (Ojima et al., 1986, 1988).

In the seventies, crosses among nectarines and peaches introduced from Florida (Sharpe, 1964; Sharpe and Aitken, 1971) led to segregation of intermediary skin color (between green and red), originating peaches with pink skin and earlier production (Ojima et al., 1988).

Later on, intercrossing $F_{1}$ 's seedlings or backcrossing to nectarines resulted in types with very red skin, large fruits, yellow and firm flesh. The breeding work allowed a range of possibilities to growers as shown in Table 2 (Barbosa et al., 1990c) and embryo culture helped a lot (Barbosa et al., 1985).

The recently released cultivar 'Douradão' has been determinant to peach producing, in areas never thought before (Barbosa et al., 2000, 2003).

\section{MATERIALS AND METHODS}

Twenty out the 58 cultivars and selections, budded on 'Okinawa' rootstock were grown, in row spacing of $4 \times 1.5 \mathrm{~m}(1,667 \mathrm{trees} / \mathrm{ha})$ and $6 \times 4 \mathrm{~m}(417$ trees/ha $)$. The experimental areas were at Limeira $\left(22^{\circ} 32^{\prime} \mathrm{S} ; 24 \mathrm{CH}-7^{\circ} \mathrm{C}\right)$, Monte Alegre do Sul $\left(22^{\circ} 41^{\prime} \mathrm{S} ; 40 \mathrm{CH}-7^{\circ} \mathrm{C}\right)$ and Itupeva $\left(23^{\circ} 05^{\prime} \mathrm{S} ; 80 \mathrm{CH}-7^{\circ} \mathrm{C}\right)$.

Traits evaluated were: numbers of buds, nodes and flowers per meter of branch; anther/flower and pollen/anther; fruit set; fruit development period; fruit characteristics; harvest season; trunk cross-sectional area; canopy volume; leaf area; yield/tree and hectare; number of fruit and mass $/ \mathrm{cm}^{2}$ of trunk.

\section{RESULTS}

Under a standard orchard system $(4 \times 6 \mathrm{~m})$, best vegetative and reproductive development were presented by: 'Talismã', 'Aurora-1', '13 and 'Flordaprince'. These selections presented on average, above 40 nodes/meter, 2.50 flower and leaf buds/node, $40 \%$ of fruit set and $65 \mathrm{~kg} / \mathrm{tree}$.

Using the meadow orchard system (Campo-Dall'Orto et al., 1984; Barbosa et al., 1989, 1991), traits obtained were as follows: largest trunk cross-sectional area and canopy volume: 'Tropical', 'Talismã', 'Aurora-1' and 'IAC 680-13' which showed above $145 \mathrm{~cm}^{2}$ and $8 \mathrm{~m}^{3}$ respectively.

After ten years experimentation (under high density), best results obtained were: 'Aurora-1', 112 fruits/tree and $9.2 \mathrm{~kg} / \mathrm{tree}$; 'IAC 680-178', 94 fruits/tree, $8.5 \mathrm{~kg} /$ tree; 'IAC 680-13', 95 fruits/tree, $8.1 \mathrm{~kg} /$ tree.

'Tropical', 'Flordaprince' and 'IAC 282-24' ripened in late September to early October, 80 days after full bloom; 'Arlequim', 'Bolão' and 'Momo' ripened in late January to early February, 200 days after full bloom.

Fruit weight was larger in 'Douradão', above $120 \mathrm{~g}$ for high density and $160 \mathrm{~g}$ in standard space.

Among the studied cultivars about $46 \%$ showed yellow flesh and $54 \%$ white flesh, $47 \%$ blush and red skin, 53\% green and yellow skin, $65 \%$ freestone and 35\% clingstone. $10 \%$ showed predisposition for canning purpose.

\section{CONCLUSIONS}

IAC cultivars harvest occurs from August to February, about 70-210 days after full bloom, respectively.

'Tropical', 'Aurora-1', 'Aurora-2', 'Régis' and 'Centenária' are the best adapted cultivars to the warm climate of São Paulo State.

'IAC 680-178' and 'IAC 680-13' are the best new peach selections for subtropical-tropical areas of São Paulo State.

'Douradão' showed better adaptation in southern areas of São Paulo State, with 100-200 chilling hours bellow $7.2^{\circ} \mathrm{C}$, between June and August. 'Douradão' fruit quality is excellent for fresh market, having good post-harvest conservation.

Using nectarines in crosses made all the difference allowing changes in skin color, 
from green to red and earlier maturation of the obtained offsprings.

\section{Literature Cited}

Barbosa, W., Campo-Dall'Orto, F.A. and Ojima, M. 2000. Pêssego Douradão. In: L.C. Donadio (org.), Novas variedades brasileiras de frutas. 1 ed. Jaboticabal: SBF, 1:176177.

Barbosa, W., Campo-Dall'Orto, F.A. and Ojima, M. 1985. Cultura de embriões in vitro, para melhoramento de pessegueiros precoces. Bragantia, Campinas 44(1):465-472.

Barbosa, W., Campo-Dall'Orto, F.A. and Ojima, M. 1989b. O pessegueiro no sistema de pomar compacto: I. Conjeturas, experimentação e prática. O Agronômico, Campinas 41(1):26-37.

Barbosa, W., Ojima, M., Campo-Dall'Orto, F.A. and Martins, F.P. 1990d. Época e ciclo de maturação de pêssegos e nectarinas do Estado de São Paulo. Bragantia, Campinas 49(2):221-226.

Barbosa, W., Ojima, M., Campo-Dall'Orto, F.A., Rigitano, O., Martins, F.P., Castro, J.L. and Santos, R.R. 1989c. 'Tropical', novo pêssego de coloração vermelha intensa e bem precoce para São Paulo. In: Congresso Brasileiro de Fruticultura, 10., Fortaleza, Anais. Fortaleza, Sociedade Brasileira de Fruticultura, p.426-430.

Barbosa, W., Ojima, M., Sampaio, V.R., Martins, F.P. and Igue, T. 1991c. O pessegueiro no sistema de pomar compacto: II. Influência das épocas de poda drástica no desenvolvimento das plantas. Campinas, Instituto Agronômico, 26p. (Boletim científico, 22).

Barbosa, W., Pommer, C.V., Ribeiro, M.D., Veiga, R.F.A. and Costa, A.A. 2003. Distribuição geográfica e diversidade varietal de frutíferas e nozes de clima temperado no Estado de São Paulo. Rev. Bras. Fruticultura, Jaboticabal 25(2):341-344.

Campo-Dall'Orto, F.A., Ojima, M., Barbosa, W., Tombolato, A.F.C., Rigitano, O. and Alves, S. 1984. Cultivo de seleções de pessegueiros precoces no sistema de pomar compacto com poda drástica. Pesquisa Agropecuária Brasileira, Brasília 19(6):719727.

Instituto Agronômico (Campinas). 1980. Cultivares lançados pelo IAC no período 19681979. O Agronômico, Campinas 32:39-168.

Ojima, M., Campo-Dall'Orto, F.A., Barbosa, W. and Rigitano, O. 1988. Desenvolvimento da fruticultura de clima temperado em São Paulo: Contribuição do Instituto Agronômico até seu centenário, 1887-1987. Campinas, Instituto Agronômico, 63p. (Documentos IAC, 11).

Ojima, M., Campo-Dall'Orto, F.A., Barbosa, W., Martins, F.P. and Rigitano, O. 1986a. Melhoramento das frutíferas de clima temperado: novos cultivares IAC. O Agronômico, Campinas 39(3):227-236.

Rigitano, O. and Ojima, M. 1971. Pêssego: novas seleções fazem o quadro se alterar. Coopercotia, São Paulo 27(256):30-31.

Rigitano, O., Ojima, M. and Campo-Dall'Orto, F.A. 1975. Comportamento de novas seleções de pêssegos introduzidos da Flórida. Campinas, Instituto Agronômico, 12p. (Circular, 46).

Sharpe, R.H. and Aitken, J.B. 1971. Progress of the nectarine. Proceedings of the Florida State Horticultural Society, Florida 84:338-345.

Sharpe, R.H. 1964. Sunred, a nectarine for Central Florida. Gainesville, University of Floria, 4p. (Circular, 5-158).

Sherman, W.B., Lyrene, P.M., Mortensen, J.A. and Sharpe, R.H. 1982. 'Flordaprince' peache. HortScience, Alexandria 17(6):988. 


\section{Tables}

Table 1. Earliness of a number of peach and nectarine cultivars available to Brazilian growers (Barbosa et al., 2000, updated for this article).

\begin{tabular}{lccc}
\hline Earliness & $\begin{array}{c}\text { Cycle } \\
\text { days }\end{array}$ & $\begin{array}{c}\text { Harvest } \\
\text { months }\end{array}$ & Cultivars \\
\hline I. Ultraprecocious & $\leq 74$ & August & Fla.7-3 $^{1}$ \\
II. Very precocious & $75-90$ & September & $\begin{array}{c}\text { Flordaprince }^{1} \text {, Tropical, Maravilha } \\
\text { Jóia-1, Dourado-1, Aurora-1, Ouromel-3, } \\
\text { Centenária, Douradão, BigAurora }\end{array}$ \\
III. Precocious & $91-120$ & October & $\begin{array}{c}\text { Canário, Cristal, Talismã } \\
\text { IV. Mid season }\end{array}$ \\
V. Late & $121-150$ & Nov.-Dec. & Biuti, Rei da Conserva, Natal \\
VI. Very late & $\geq 181$ & Jan.-Feb. & Bolão, Arlequim, Momo \\
Introduced from University of Florida, Gainesville, USA (Sherman et al., 1982).
\end{tabular}

